\title{
TAXATION AND ECONOMIC GROWTH: A REGRESSION ANALYSIS BASED ON A NEW CLASSIFICATION
}

\author{
Lich Khac Hoang ${ }^{\prime *}$, Binh Tan $\mathrm{CaO}^{2}$, Kim My Le ${ }^{2}$ and Dung Thi Thuy Nguyen² \\ VVietnam National University, University of Economics and Business, Hanoi, Vietnam \\ ${ }^{2}$ Quy Nhon University, Quy Nhon, Vietnam
}

This paper examines the impact of taxes on the economic growth based on classifying countries by GDP per capita and a tax burden. The Partitioning Around Medoids (PAM) technique is used because it is not too sensitive to outliers. Through this multicriteria classification technique, the Generalized Method of Moments (GMM) is employed to analyze the data of the three groups consisting of 63 countries from 2003 to 2017. The results show that most taxes have a positive impact on economic growth in poor countries (Group 1). Interestingly, taxes on goods and services promote economic growth in rich countries (Group 3), rather than having a negative effect, as is concluded by some previous studies. Specially, while the property tax has a negative effect on economic growth in rich countries, its impact is significantly positive in poor countries.

Keywords: tax structure, economic growth, clustering technique, GMM estimation

JEL Classification: E62, Ho, 047

\section{INTRODUCTION}

The relationship between tax and economic growth has attracted a lot of attention in recent years. Theoretically, endogenous growth models show that the accumulation of productive capital can promote long-term economic growth. Therefore, any tax policy that changes the accumulation of physical capital and/or human capital can affect long-term economic growth (Romer, 1986; Lucas Jr, 1988; Barro,

* Correspondence to: L. K. Hoang, Vietnam National University, University of Economics and Business, No.144

Xuan Thuy street, Cau Ciay, Hanoi, Vietnam;

e-mail: hoangkhaclich@gmail.com
1990). However, this effect can be either positive or negative because raising tax increases the likelihood of government spending, on the one hand, and crows out private investments, on the other.

According to I. Palić, B. Žmuk and B. Grofelnik (2017), the impact of taxes on economic growth depends on the structure of the tax system. A proper tax system will help a government achieve national fiscal goals most effectively, limit undesirable distortions, minimize welfare losses, and ultimately promote economic growth (Stoilova, 2017). Previous research papers state that every adjustment of tax components can influence economic growth. For 
example, R. Kneller, M. F. Bleaney and N. Gemmell (1999), J. M. Arnold, B. Brys, C. Heady, Å. Johansson, C. Schwellnus and L. Vartia (2011) and D. Baiardi, P. Profeta, R. Puglisi and S. Scabrosetti (2019) suggest that reducing the proportion of direct tax and increasing the proportion of indirect tax will positively impact economic growth. This adjustment is both to secure the budget revenue and to facilitate investment in the private sector.

It is worth noting that the tax structure may be optimal in one country, but it may not be as good in other countries, due to many reasons such as differences in the economic structure, political characteristics, society, a tax burden and governments' management ability. For instance, Sweden has a tax-to-GDP ratio of $43.9 \%$, while the OECD countries' ratio is about $34.3 \%$. Sweden's personal income tax rate is about $57 \%$, the highest among all European countries, but its corporate income tax rate is the lowest, about $22 \%$. It cannot be generalized that European countries or the US should learn from Sweden, or conversely, that Sweden should learn from the US's or European's tax systems because of the differences in the context of each country. In order to learn valuable lessons in restructuring the tax system, a good way is to examine a group of countries which are similar in terms of the level of economic development and the tax burden.

In fact, to examine different groups of countries, many studies have applied the classification of the World Bank (WB) or the International Monetary Fund (IMF). However, the WB and the IMF only use one criterion to classify countries, normally based on their geographical area or the GNI per capita. This classification ignores the similarities on other aspects, such as the ones related to a country's tax system. Additionally, some studies classify countries based on their own criteria: for example, A. Vasiliauskaite and E. Stankevičius (2009) divide the European countries into six groups by GDP per capita with an equal income gap of EUR 5000/per capita before assessing the impact of a tax burden on economic growth. Similarly, P. LeMay-Boucher and K. McNabb (2014) and S. AcostaOrmaechea, S. Sola and J. Yoo (2019) arrange countries into three groups based on the GDP per capita by the three-percentile threshold, 33\% and 66\%, respectively. However, the equidistant grouping cannot highlight the similarities between the countries within the same group, and thus suggests applying a strictly statistical technique to identify the thresholds between the groups.

To the best of our knowledge, there are not many research studies on the fiscal policy classification of countries based purely on statistical techniques such as a classification by more than one criterion. Recently, A. Andrejovská and M. Hudáková (2016) have used a nonhierarchical clustering method, such as the K-means and the fuzzy c-means to divide the EU countries into five groups based on the common characteristics including corporate income tax, economic performance, and the public debt ratio. M. Zaharia, A. Pătrașcu, M. Gogonea, A. Tănăsescu and C. Popescu (2017) use hierarchical clustering to classify the EU-28 member states by a criterion representing the energy tax policy. In general, the common purpose of these works is to group countries with similarities in economic and fiscal indicators, depending on the research purpose of each paper. Under these classifications, each country's policy design has more information for reference; furthermore, making a general policy for the whole group becomes more effective.

A new classification method appropriate for doing research in the impact of taxes on economic growth is approached in this paper. Among the popular classification techniques, the Partitioning Around Medoids (PAM) clustering technique was chosen, because it is not too sensitive to outliers. Moreover, under small data sample conditions, PAM is considered to have good cluster performance (Kaufman \& Rousseeuw, 1990; Park \& Jun, 2009). In particular, countries are simultaneously classified according to the two criteria: the GDP per capita and a tax burden. Firstly, the development level of a country is reflected by its GDP per capita. Although this indicator is a single index showing the average income of people in the territory of a country, it implies a lot of information about the economic development level. Hence, it lays the basis for the classification of the World Bank intended to categorize countries as either 
developed or developing ones. Secondly, a tax burden is measured by the ratio of tax to the GDP, indicating the proportion of the income that economic agents contribute to the government budget.

Thanks to the PAM clustering technique, the impact of the six types of taxes (namely corporate income tax, personal income tax, social security contributions, good and services tax, trade tax, and property tax) on economic growth is examined in three groups of countries. As will be seen later, average income and a tax burden gradually increase from Group 1 to Group 3. According to the foregoing, the hypotheses of this study read as follows:

H1: Personal income tax has a negative effect on economic growth.

H2: Corporation income tax negatively impacts economic growth.

H3: Property tax promotes economic growth.

H4: Trade tax positively affects economic growth.

H5: Goods and service tax has a negative effect on economic growth.

H6: Social security contribution negatively influences economic growth.

Stationary and cointegration tests are performed prior to using the difference and system generalized method-of-moments (GMM) estimators in order to examine the impact of taxes on economic growth. The data sample is the well-balanced panel data of 63 countries with 945 observations collected from the World Bank's database from 2003 to 2017.

The remaining part of the paper is structured as follows: the literature review is presented in Section 2 , and the data and the methodology are presented in detail in Section 3; Section 4 is dedicated to the discussion on the research findings and the conclusion, and some policy suggestions are provided in Section 5.

\section{LITERATURE REVIEW}

\section{The theoretical perspective}

Theoretical models have described the mechanism in which taxes affect economic growth. Particularly, neoclassical models (Engen \& Skinner, 1996; Lin, 1998; Zagler \& Dürnecker, 2003) point out five channels, including:

- increasing corporate income and personal income taxes leads to a decrease in disposable income, which in turn results in a reduction of the savings rate, thus discouraging investment;

- increasing tax may encourage individuals to take up more leisure, which may lead to a decrease in the total labor supply, which negatively affects production;

- increasing tax restrains an improvement in labor productivity because it limits R\&D activities and reduces the amount of venture capital for hightech industries;

- taxes can reduce the marginal product of capital as it reduces investment in the high-productivity and high-tax economic sectors and makes an increase in the low-productivity and low-tax ones;

- increasing personal income tax may discourage workers from working in highly productive industries, but with a large tax burden.

However, neoclassical models argue that taxes do not affect long-term economic growth because the factors including savings and investments will only lead to growth in the short run. The law of the diminishing marginal product of capital will force the economy toward a stable state, where growth only depends on technological progress - which is considered as an exogenous factor in the model. Therefore, governments cannot control economic growth in the long run by fiscal policies. In contrast, endogenous growth models such as the AK model (Romer, 1986, Barro, 1990), the R\&D model (Grossman \& Helpman, 1991) and the human capital model (Lucas Jr, 1988) argue that taxes can have an impact on growth 
in the long run. Specifically, capital is categorized into two types: physical capital and human capital. Investment in human capital leads to growth in the long run as it does not follow the law of diminishing marginal product. Thus, governments can provide tax incentives to encourage investment in education or to encourage the development of knowledge-intensive industries.

\section{Empirical findings}

There is a vast body of the literature examining the impact of taxes on economic growth. The previous studies approach the topic in various manners, such as by using different methods and datasets. Therefore, the results are usually inconsistent.

\section{The impact of the corporate income tax}

Most studies show that increasing the rate of the corporate income tax reduces net income and limits capital for reinvestment activities, especially for the investment activities related to productivity improvement, such as innovation and R\&D, thereby affecting the overall productivity of the economy (Johansson, Heady, Arnold, Brys \& Vartia, 2008; Karras \& Furceri, 2009; Gemmell, Kneller \& Sanz, 2011; Edame \& Okoi, 2014). In addition to this, a high corporate income tax restricts FDIs, hindering technology transfer and knowledge sharing to local enterprises and consequently restraining economic growth. For example, Arnold et al (2011) examine the effect of income taxes on economic growth in the 21 OECD countries over the period from 1971 to 2004. The paper estimates the long-term effects of various revenue-neutral tax shifts using the estimated dynamic equation. The results show a negative coefficient on the share of (personal and corporate) income taxes in the total tax revenues, indicating that an increase in the share of these taxes that is balanced by a decrease in the share of the consumption and property taxes will reduce the long-term GDP per capita, thus reducing economic growth.

\section{The impact of the personal income tax}

An increase in the personal income tax, on the one hand, creates a substitution effect. Under the substitution effect, workers tend to replace working with leisure, which negatively affects economic growth. On the other hand, the personal income tax also causes income effects: as net income decreases, workers tend to cut on leisure to focus on working in order to compensate for taxed income. Furthermore, a rise in this tax demotivates learners' efforts as they perceive fewer benefits from learning, which consequently degrades the quality of labor and negatively affects economic growth. If used to invest in the infrastructure and education, however, this tax revenue will contribute to the quality of labor and economic growth (McClelland \& Mok, 2012).

Many studies confirm the negative impact of the personal income tax on economic growth (Kneller et al, 1999; Widmalm, 2001; Gemmell et al, 2011). Notably, F. Widmalm (2001) finds a robust negative correlation between the two variables in the 23 OECD countries during the period from 1965 to 1990 . This finding is consistent with the hypothesis that a progress tax is harmful for economic growth under a given tax rate since the personal income tax is levied in a progressive fashion in the largest number of the Western countries. By contrast, D. Stoilova (2017) applies two-stage least square (2SLS) estimates to show the positive effect of the personal income tax on economic growth in the EU-28 member states over the period between 1996 and 2013.

\section{The impact of the goods and services tax}

If the personal income tax is considered a progressive tax, the goods and services tax can be considered a regressive tax, in which the tax burden is put on the end users instead of suppliers - taxpayers. Moreover, the goods and services tax puts more pressure on the low-income group rather than the high-income one, because both these groups pay the same amount of tax when they consume goods and services. Unlike the personal income tax, the goods and services tax directly affects the market price and the inflation rate. 
Thus, it might encourage savings, which leads to an increase in investment and economic growth.

The greatest number of empirical studies find that the goods and services tax negatively affects growth: for instance, the case of the 26 OECD countries (Karras \& Furceri, 2015) and the case of the EU28 countries (Stoilova, 2017). There are only a few studies claiming the positive impact of the goods and services tax on economic growth (Baiardi et al, 2019). The inconsistency in the findings might be due to the different taxation methods in each country. More specifically, if the goods and services tax is equally imposed on all products, it will have the same effect as the income tax. In the case of an unequally imposed tax, which is only applied to certain goods and services, the consumer's decision to make a purchase may be changed; this in turn leads to an expansion of or a decline in industries. The goods and services tax can promote economic growth if expansion is greater than the decline (Zagler \& Dürnecker, 2003). If a goods and services tax policy is unstable and often changed, it will alter consumers' consumption choices, thus leading to a nonoptimal resource allocation. The imposition of the goods and services tax may result in the expansion of illegal economic activities, particularly so in more transactions on the black market, thus leading to a miscalculated GDP.

\section{The impact of the property tax}

Several research studies have found that the property tax negatively impacts economic growth (Xing, 2012; Baiardi et al, 2019). For instance, when property transactions or real estates are taxed, investors make incentives to transfer their investment from the real estate sector to the activities generating a bigger profit, and the economy consequently grows (Arnold et al, 2011). Besides, the property tax is considered to be an effective tax, because it barely touches the resource distribution and has a smaller impact on economic behaviors than the personal income tax does. The property tax is an efficient fund of local public services aiming to stimulate the growth of the economy and social welfare (Slack \& Bird, 2014). In contrast to this, G. Karras and D. Furceri (2009) find a negative impact of the property tax on economic growth, but the obtained result is not statistically significant. In spite of the vague argument, the property tax applied to housing transactions limits the transactions transferring real estate ownerships. Moreover, investment capital tends to be more mobile than housing capital, and investment properties should be taxed less than housing properties in order to stimulate the economy. In reality, however, investment capital is taxed more than housing capital, and the difference made by the property tax leads to a false decision on the property usage and promotes the personal usage of a property instead of the commercial and industrial usage of a property (Paugam \& Maurer, 2001).

\section{The impact of the trade tax}

There is a debate among economists over whether taxes on international trade boost economic growth or not. S. Acosta-Ormaechea et al (2019), for example, study the relationship between trade taxes and the economic growth of 70 countries during the period between 1970 and 2009. The authors find that trade taxes have different effects on the economic growth of different country groups. In particular, trade taxes seem to have a negative impact on economic growth for low-income countries. Similarly, I. Khujamkulov (2016) states that trade taxes are often the major sources of revenue in lower-middle-income transitional countries, because they are easier and less costly to collect than income taxes. This result is found in 33 transition countries over the period from 1991 to 2014. Interestingly, N’Y. Nantob (2014) uses the system GMM estimator to analyze the effects of taxes on the economic growth of 47 developing countries during the period from 2000 to 2012. This study finds that there is a nonlinear (U-shaped) relationship between taxes on international trade and economic growth. This means that a low-level tax rate discourages economic growth in the short run, and then stimulates economic growth as the tax level increases. 


\section{The impact of the social contribution tax}

The prior literature is often inconsistent with respect to the impact of the social contribution tax on economic growth. For example, while D. Stoilova (2017) reports a positive impact, R. Macek (2015), G. Karras and D. Furceri (2009) find a negative one. In particular, R. Macek (2015) evaluates the impact of taxes on economic growth by utilizing panel regression analysis on the OECD countries over the period from 2000 to 2011. The author states that the social security contribution is the most harmful for economic growth. In addition, the results also indicate that the government spending decreases economic growth. These results can be most probably linked to the existence of the crowding out effect and the structure of the total government spending where unproductive spending predominates. Unproductive spending is connected to the spending on social security, which has as the ultimate consequence a lower rate of economic growth. As far as the tax burden approximated by the tax quota is concerned, there is a negative relationship between economic growth and social security contributions.

\section{DATA AND METHODOLOGY}

\section{Data}

In this research study, the countries are classified based on the two criteria, simultaneously including the GDP per capita and the tax burden collected from the World Bank's database. The tax burden is measured by the total tax revenue on the GDP and is the indicator representing a country's tax policy. The GDP per capita is used as the indicator representing the economic development of a country (Wang, 2007). The control variables in the regression model are exports, savings, the investment rate in physical capital (as a percentage of the GDP), population growth, inflation (collected from the World Bank), and human development index (i.e, HDI, collected from the UNDP database). Finally, the taxes including the goods and services tax, the trade tax, the property tax, the corporate income tax, the personal income tax, and social security contributions (measured by the tax/GDP ratio) are collected from the government revenue dataset.

Dropping out the countries that lack all the data pertaining to the period from 2003 to 2017, there are the data of 117 countries from the original dataset of 217 countries. Then, the countries are clustered according to the GDP per capita and the tax burden. The PAM result shows that the countries should be divided into three groups for all the years (Figure 1 and Figure 2). Average income and the tax burden gradually increase from Group 1 to Group 3. After the addition of the control variables to the clustered dataset and after the elimination of the countries containing the missing data for five consecutive years, a balanced data table of 945 observations of the 63 countries are obtained.

In terms of the tax structure, a large proportion in the total tax revenue is accounted for the goods and services tax, social security contributions, the personal income tax and the corporate income tax. The goods and services tax and social security contributions make up the biggest share of the total tax in the developed countries (Group 2 and Group 3). The personal income tax and social security contributions gradually increase from Group 1 to Group 3. In addition, the goods and services tax is the highest in Group 2. The trade tax decreases from Group 1 to Group 3, which is aligned with the findings of the previous studies (Bird \& Zolt, 2008; LeMay-Boucher \& McNabb, 2014).

\section{Methodology}

According to Y. Lee and R. H. Gordon (2005), the tax structure of rich countries is often different from that of the poor. Therefore, ignoring differences among countries can lead to endogeneity. By clustering countries with similarities in the GDP and the tax burden, said endogeneity was partly overcome. In order to cluster the countries, the PAM technique is used. This technique effectively processes noise data and the presence of outliers. The PAM algorithm proposed by L. Kaufman and P. J. Rousseeuw (1990) 


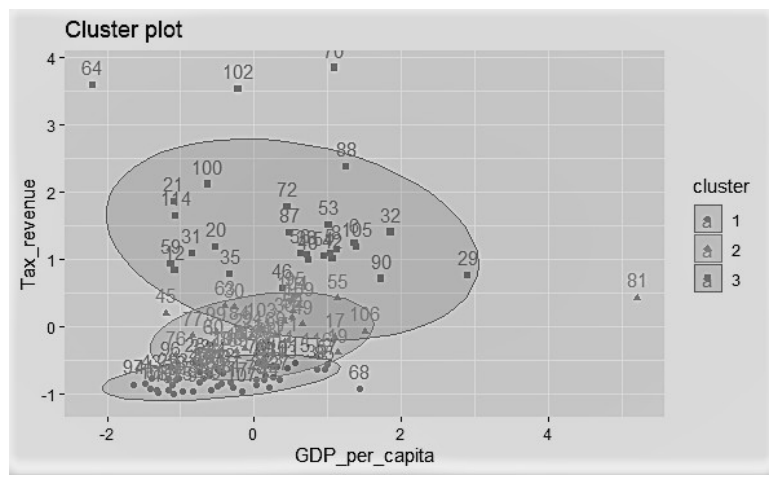

Figure 1 The country clusters in 2003

Source: Authors

is an extension of the K-Means algorithm that uses a medoid to represent data clusters (a medoid is the object located at the center of each cluster). Therefore, the medoid is less affected by particles far from the center. PAM initializes the k-medoid objects and distributes the remaining objects into the clusters corresponding to the other medoid objects, so that they are the most similar to the medoid object. The PAM algorithm helps find the countries that are virtually stable in each cluster over a period of 15 years (2003-2017). The number of the clusters is predicted by the Elbow method (Makles, 2012). The effectiveness of the clustering is based on the average of the silhouette index. The results show that the average silhouette is quite stable, the highest being 0.58 in 2017, and the lowest being 0.52 in 2008. The index also shows the highest similarity in Group 1 and the lowest similarity in Group 3.

After clustering the countries, panel regression analysis is carried out so as to examine the impact of the taxes on economic growth for every country group. Capital accumulation is considered the most important factor determining the growth of the economy (Rodrik, 1994; Lee, 1995). Both the classical growth models and the endogenous growth models indicate that economic growth is stimulated through the accumulation of physical capital and human capital (Solow, 1957; Lucas, 1988; Barro, 1990). To accumulate capital, a nation needs to create savings, invest from household savings, and accumulate

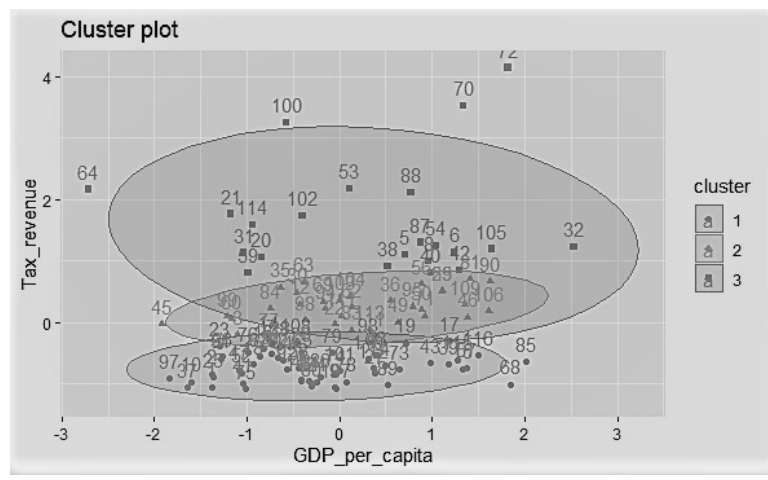

Figure 2 The country clusters in 2017

Source: Authors

through the government policy. The countries with a high household savings rate tend to have a higher physical capital investment rate, which leads to the expansion of business activities and thus to the growth of the economy. The accumulation of physical capital also funds the fundamental public services such as the public infrastructure, the education expense, and the healthcare expense in order to support economic growth. In addition, the human development index (HDI) is also a measurement of the development level because it takes into account education through the adult literacy rate, the years of schooling, healthcare, and income. The other control variables in the regression equation are the population growth rate (Widmalm, 2001; Lee \& Gordon, 2005), the savings (Lin, 1998), the export to the GDP ratio (Frankel \& Romer, 1999; Dollar \& Kraay, 2003), and the inflation rate (Friedman, 1977; Stockman, 1981).

Thus, the regression equation is written down as follows:

$$
Y_{i t}=\beta_{0}+\beta_{1} Y_{i t-1}+\beta_{2} T_{i t}+\beta_{3} X_{i t}+\varepsilon_{i}
$$

where:

$Y_{i t}$ is the growth rate of the GDP per capita; $T_{i t}$ includes the tax variables: the corporate income tax, the personal income tax, the social security contributions, the goods and services tax, the trade tax, the property tax, and the other tax (in \% of the GDP); $X_{i t}$ includes the control variables: population growth, gross 
savings, export to the GDP ratio, the total tax burden, the human development index, the investment rate in physical capital and the inflation rate.

The panel data properties are tested for the stationarity and cointegration. The dependent variable (the growth rate of the GDP per capita) is found to be stationary for every country group. A decision was made to use the explanatory variables at the level data instead of the variable in the form of the differences, given the fact that the explanatory power with the R-squared by estimating the model with the explanatory variables in the form of the differences is weaker than that originating from the regression using the explanatory variables at the level data. To solve the endogenous problems more effectively, the generalized methodof-moments estimators are used. The instrumental variables are the lagged tax variables. The degree of the lagged variables is determined based upon the partial correlation test. The largest number of the instrumental variables in the three groups are oneyear lagged variables. The J-statistic results confirm the proper use of the instrumental variable in the GMM regression (Table 1).

\section{RESULTS}

The conducted analysis provides the six main results.

First, the personal income tax is found to negatively affect the GDP per capita growth rate of the Group 1 countries (the poor countries group). Specifically, if the personal income tax increases by $1 \%$, then these countries' GDP per capita growth rate will decline by $0.596 \%$. The finding proves that the substitution effect overwhelms the income effect in Group 1. Additionally, increasing the personal income tax rate may demotivate the labor force because they notice a decline in the education benefit. The finding aligns with the hypothesis $\mathrm{H} 1$ of the paper and the previous studies by N. Gemmell, R. Kneller and I. Sanz (2011), F. Widmalm (2001), and R. Kneller et al (1999). However, no evidence whatsoever can be found for the impact of the personal income tax on the economic growth rate in Group 2 and Group 3 (the richer countries groups).
Second, the regression result indicates that the corporate income tax has a positive effect on the economic growth rate in both Group 1 and Group 2. Specifically, an increase of $1 \%$ in the corporate income tax raises the GDP per capita growth rate by $0.223 \%$ and $1.09 \%$ in Group 1 and Group 2, respectively. Therefore, the hypothesis $\mathrm{H} 2$ can be rejected. The finding is also aligned with the finding of D. Stoilova (2017). A possible explanation for this finding is that the corporate income tax is an important source of tax revenue funding investments in public services, which usually need to be paid more attention to in developing countries. Thus, the economic growth rate benefits from the corporate income tax.

Third, the goods and service tax is found to have a negative effect on the economic growth of Group 2, whereas it has a positive effect on the economic growth of Group 3. The finding is in contrast with the hypothesis $\mathrm{H} 5$ and the majority of the previous studies stating that the goods and services tax has a negative effect on economic growth. The result obtained in this research study is consistent with the study by D. Baiardi et al (2019. One possible explanation for that is that, even though the increase in underground economic activities cannot be quantified, it increases income for some economic sectors anyway (Johansson et al, 2008). This additional income also finances expenditures and investments, thus boosting economic growth. In addition, an uneven increase in the goods and services tax may lead to the expansion of or a decline in some economic sectors. As a result, economic growth can be promoted if the expansion portion is greater than the decline portion (Zagler \& Dürnecker, 2003).

Fourth, the property tax has a significant positive impact on the economic growth rate of the Group 1 countries. The result shows that an increase of $1 \%$ in the property tax raises the GDP per capita growth rate by $2.012 \%$, and the finding matches the hypothesis $\mathrm{H} 3$ and many other studies such as J. M. Arnold et al (2011) and S. Acosta-Ormaechea et al (2019). It is worth noticing that the property tax revenue only contributes $0.2 \%$ to the GDP on average (the lowest between the three groups). The results, however, show that there is a negative impact of the property tax on the GDP per capita growth rate in Group 3, which is 
Table 1 The GMM regression results

\begin{tabular}{|c|c|c|c|}
\hline & Cluster 1 & Cluster 2 & Cluster 3 \\
\hline Personal income tax & $\begin{array}{c}-0.596^{* * *} \\
(0.000)\end{array}$ & $\begin{array}{c}0.191 \\
(0.166)\end{array}$ & $\begin{array}{c}0.952 \\
(0.254)\end{array}$ \\
\hline Corporate income tax & $\begin{array}{l}0.223^{*} \\
(0.096)\end{array}$ & $\begin{array}{l}1.090^{*} \\
(0.057)\end{array}$ & $\begin{array}{l}-0.706 \\
(0.627)\end{array}$ \\
\hline Property tax & $\begin{array}{c}2.012^{* * *} \\
(0.001)\end{array}$ & $\begin{array}{l}-0.390 \\
(0.218) \\
\end{array}$ & $\begin{array}{c}-4.899^{* *} \\
(0.018)\end{array}$ \\
\hline Goods and services tax & $\begin{array}{l}-0.0228 \\
(0.796) \\
\end{array}$ & $\begin{array}{l}-0.416^{* *} \\
(0.048) \\
\end{array}$ & $\begin{array}{l}2.660^{* *} \\
(0.047)\end{array}$ \\
\hline Trade tax & $\begin{array}{l}0.476^{* *} \\
(0.042) \\
\end{array}$ & $\begin{array}{c}3.064 \\
(0.280) \\
\end{array}$ & $\begin{array}{l}10.289 \\
(0.522)\end{array}$ \\
\hline Other tax & $\begin{array}{c}0.204 \\
(0.656)\end{array}$ & $\begin{array}{l}-1.029^{* *} \\
(0.045)\end{array}$ & $\begin{array}{l}-31.820 \\
(0.206)\end{array}$ \\
\hline Social Security Contribution & $\begin{array}{l}-0.041 \\
(0.640)\end{array}$ & $\begin{array}{c}0.225 \\
(0.109) \\
\end{array}$ & $\begin{array}{c}-1.717^{* *} \\
(0.021)\end{array}$ \\
\hline Investment rate & $\begin{array}{c}0.173^{* * *} \\
(0.000)\end{array}$ & $\begin{array}{c}0.226^{* * *} \\
(0.000)\end{array}$ & $\begin{array}{c}0.202^{* * *} \\
(0.000)\end{array}$ \\
\hline Inflation & $\begin{array}{c}-0.176^{* * *} \\
(0.000)\end{array}$ & $\begin{array}{c}-1.745^{* *} \\
(0.019) \\
\end{array}$ & $\begin{array}{c}0.285 \\
(0.391) \\
\end{array}$ \\
\hline Export to GDP & $\begin{array}{l}-0.019 \\
(0.172) \\
\end{array}$ & $\begin{array}{l}-0.006 \\
(0.511) \\
\end{array}$ & $\begin{array}{c}0.028 \\
(0.649) \\
\end{array}$ \\
\hline Population growth & $\begin{array}{c}-0.912^{* * *} \\
(0.000)\end{array}$ & $\begin{array}{l}-1.879^{* *} \\
(0.012)\end{array}$ & $\begin{array}{l}-2.850^{*} \\
(0.106)\end{array}$ \\
\hline Gross saving & $\begin{array}{c}0.016 \\
(0.456) \\
\end{array}$ & $\begin{array}{l}0.164^{*} \\
(0.079) \\
\end{array}$ & $\begin{array}{c}0.368 \\
(0.313) \\
\end{array}$ \\
\hline Human development index & $\begin{array}{l}-1.459 \\
(0.683) \\
\end{array}$ & $\begin{array}{l}10.248 \\
(0.482) \\
\end{array}$ & $\begin{array}{l}-28.926 \\
(0.652) \\
\end{array}$ \\
\hline Observations & 364 & 247 & 208 \\
\hline Sargan test - Prob $>$ chi $^{2}$ & 0.297 & 0.204 & 0.187 \\
\hline
\end{tabular}

Note: * Significant at $10 \%, * *$ Significant at $5 \%, * * *$ Significant at $1 \%$

Source: Authors

the group with the highest property tax revenue to the aggregate GDP ratio (nine times higher than the Group 1). The finding aligns with the research studies conducted by A. Paugam and R. Maurer (2001) and M. Cabral and C. Hoxby (2012).

Fifth, the social security contributions have a negative relationship with the economic growth of the Group 3 countries, which is similar to the findings of $\mathrm{G}$. Karras and D. Furceri (2009). If this type of tax increases by $1 \%$, the countries' GDP per capita growth rate will decrease by $1.717 \%$ for Group 3, which has the highest social security contribution rate by up to $9 \%$. This result is also completely consistent with the hypothesis H6. The reason for this is that social security contributions finance social welfare, which largely do not generate economic growth, but rather have a negative impact on economic growth (Feldstein, 1974). 
Sixth, the findings show that the trade tax does not affect economic growth in Groups 2 and 3, whereas it has a positive effect on economic growth in Group 1. Specifically, a $1 \%$ increase in the trade tax may lead to an increase in the GDP per capital growth rate for Group 1 by $0.476 \%$. This outcome is in line with the findings of M. S. Tosun and S. Abizadeh (2005); O. H. Fjeldstad (2013); N'Y. Nantob (2014) and I. Khujamkulov (2016).

Several other control variables in the model also affect the GDP per capita growth rate. The investment rate has a positive impact on economic growth in all the three groups. Nonetheless, the population growth rate has a negative relationship with the dependent variable. In addition to those two control variables, inflation has a negative impact on economic growth both in Group 1 and in Group 2, while there is significant relationship in Group 3. Finally, the gross savings rate coefficient has no statistical significance in Group 1 and Group 3 but is statistically significant in Group 2. To conclude, the effect of the control variables mostly aligns with the prior studies.

\section{CONCLUSION}

The paper focuses on the relationship between the six types of taxes and the economic growth of 63 countries over the period from 2003 to 2017. The results show that only the personal income tax is statistically significant and negatively impacts the GDP per capita growth rate in Group 1, whereas the trade tax is only positive in this group. The social contribution tax is significant and negative in Group 3. The corporate income tax has a positive effect on economic growth in Group 1 and Group 2. The property tax is positively related in Group 1, whereas it is negative in Group 2. In contrast to this, the goods and services tax is negative in Group 2 and positive in Group 3. In addition, the impact of the control variables is also significantly noticeable. The investment rate in physical capital has a positive and significant effect on economic growth across all the three groups. Besides, inflation and population growth are negatively related to economic growth.
This paper contributes to the empirical literature on taxation by integrating and extending theoretical and empirical studies on the relationship between the tax structure and economic growth. An important finding is that a tax burden causes differences in the countries' tax structures, and different types of taxes have different effects on economic growth. Therefore, the article focuses on analyzing the impact of the tax structure on economic growth by grouping the countries based on the economic development level and the tax policy. This study has been successful in reclassifying the countries using the PAM clustering method to identify the three highly similar groups in terms of the GDP per capita and the tax burden. According to this classification, Group 1 includes the countries with low-to-moderate income (as defined by the World Bank). Some moderate-to-high and highincome countries fall into Group 2. The remaining wealthiest countries fall into Group 3.

Based on this classification, the analysis of the impact of the six types of taxes on economic growth in each group is a new and valuable contribution made by this research study. The paper, however, also faces difficulties in the missing data over many years. Adding the missing data from other reliable sources could be a good solution to increase the number of observations and expand the research period. Moreover, due to the limitations of the paper, no comparison has been made between the regression analysis results based on the classification presented in this paper and the findings based on the classification of the WB and other organizations. That may be an interesting research direction in subsequent papers.

\section{ACKNOWLEDGEMENTS}

This work was supported by the Vietnam National Foundation for Science and Technology Development (NAFOSTED) under the grant numbers 502.012018.308. 


\section{REFERENCES}

Acosta-Ormaechea, S., Sola, S., \& Yoo, J. (2019). Tax composition and growth: A broad cross-country perspective. German Economic Review, 20(4), 70-106. doi.org/10.1111/geer.12156

Andrejovská, A., \& Hudáková, M. (2016). Classification of $\mathrm{EU}$ countries in the context of corporate income tax. Acta Universitatis Agriculturae et Silviculturae Mendelianae Brunensis, 64(5), 1699-1708. doi.org/10.11118/ actaun201664051699

Arnold, J. M., Brys, B., Heady, C., Johansson, Å., Schwellnus, C., \& Vartia, L. (2011). Tax policy for economic recovery and growth. The Economic Journal, 121(550), 59-80. doi.org/10.1111/j.1468-0297.2010.02415.x

Baiardi, D., Profeta, P., Puglisi, R., \& Scabrosetti, S. (2019). Tax policy and economic growth: Does it really matter? International Tax and Public Finance, 26(2), 282-316. doi.org/10.1007/s10797-018-9494-3

Barro, R. J. (1990). Government spending in a simple model of endogeneous growth. Journal of political economy, 98(5, Part 2), 103-125. doi/abs/10.1086/261726

Bird, R. M., \& Zolt, E. M. (2008). Tax policy in emerging countries. Environment and Planning C: Government and policy, 26(1), 73-86. doi.org/10.1068/cav3

Cabral, M., \& Hoxby, C. (2012). The hated property tax: Salience, tax rates, and tax revolts. NBER Working Paper, No.18514.

Dollar, D., \& Kraay, A. (2003). Institutions, trade, and growth. Journal of monetary economics, 50(1), 133-162. doi.org/10.1016/ S0304-3932(02)00206-4

Edame, G. E., \& Okoi, W. W. (2014). The impact of taxation on investment and economic development in Nigeria. Academic Journal of Interdisciplinary Studies, 3(4), 209-218. doi.org/10.36941/ajis

Engen, E. M., \& Skinner, J. (1996). Taxation and economic growth. National tax journal, 49(4), 617-642.

Feldstein, M. (1974). Social security, induced retirement, and aggregate capital accumulation. Journal of political economy, 82(5), 905-926. doi.org/10.1086/260246

Fjeldstad, O. H. (2013). Taxation and development: A review of donor support to strengthen tax systems in developing countries. UNU-Wider Working paper.
Frankel, J. A., \& Romer, D. H. (1999). Does trade cause growth? American economic review, 89(3), 379-399. doi.org/10.1257/ aer.89.3.379

Friedman, M. (1977). Nobel lecture: Inflation and unemployment. Journal of political economy, 85(3), 451-472. doi.org/10.1086/260579

Gemmell, N., Kneller, R., \& Sanz, I. (2011). The timing and persistence of fiscal policy impacts on growth: Evidence from OECD countries. The Economic Journal, 121(550), 33-58. doi.org/10.1111/j.1468-0297.2010.02414.x

Grossman, G. M., \& Helpman, E. (1991). Trade, knowledge spillovers, and growth. European economic review, 35(2-3), 517-526. doi.org/10.1016/0014-2921(91)90153-A

Johansson, Å., Heady, C., Arnold, J., Brys, B., \& Vartia, L. (2008). Taxation and economic growth. Working Papers No 620, OECD Economics Department. doi.org/10.1787/18151973

Karras, G., \& Furceri, D. (2009). Taxes and growth in Europe. South-Eastern Europe Journal of Economics, 7(2), 181-204.

Kaufman, L., \& Rousseeuw, P. J. (1990). Finding Groups in Data: An Introduction to Cluster Analysis. New Jersey, NJ: John Wiley \& Sons.

Khujamkulov, I. (2016). Tax revenues in transition countries: Structural changes and their policy implications, WIDER Working Paper, No. 2016/180

Kneller, R., Bleaney, M. F., \& Gemmell, N. (1999). Fiscal policy and growth: Evidence from OECD countries. Journal of Public Economics, 74(2), 171-190. doi.org/10.1016/S00472727(99)00022-5

Lee, J. W. (1995). Capital goods imports and long-run growth. Journal of Development Economics, 48(1), 91-110.

Lee, Y., \& Gordon, R. H. (2005). Tax structure and economic growth. Journal of Public Economics, 89(5-6), 1027-1043. doi.org/10.1016/j.jpubeco.2004.07.002

LeMay-Boucher, P., \& McNabb, K. (2014). Tax structures, economic growth and development. ICTD Working Paper 22, Available at SSRN. doi.org/10.2139/ssrn.2496470

Lin, S. (1998). Labor income taxation and human capital accumulation. Journal of Public Economics, 68(2), 291-302. doi.org/10.1016/S0047-2727(97)00094-7 
Lucas Jr, R. E. (1988). On the mechanics of economic development. Journal of monetary economics, 22(1), 3-42. doi.org/10.1016/0304-3932(88)90168-7

Macek, R. (2015). The impact of taxation on economic growth: Case study of OECD countries. Review of Economic Perspectives, 14(4), 309-328, doi.org/10.1515/revecp-2015-0002

Makles, A. (2012). Stata tip 110: How to get the optimal k-means cluster solution. The Stata Journal, 12(2), 347-351. doi.org/10.1177/1536867X1201200213

McClelland, R., \& Mok, S. (2012). A review of recent research on labor supply elasticities. Working Paper 2012-12, Washington, DC: Congressional Budget Office.

Nantob, N'Yilimon. (2014). Taxes and economic growth in developing countries: A dynamic panel approach. MPRA Paper No. 61346, Togo, University of Lome.

Palić, I., Žmuk, B., \& Grofelnik, B. (2017). The long-run impact of personal income taxation on economic development: Evidence from Croatia. Croatian Review of Economic, Business and Social Statistics, 3(1), 35-44. doi.org/10.1515/ crebss-2017-0003

Paugam, A., \& Maurer, R. (2001). Reform toward ad valorem property tax in transition economies: Fiscal and land use benefits. Background Series 13, World Bank.

Park, H. -S., \& Jun, C. -H. (2009). A simple and fast algorithm for K-medoids clustering. Expert systems with applications, 36(2), 3336-3341. doi.org/10.1016/j.eswa.2008.01.039

Rodrik, D. (1994). Distributive politics and economic growth. Quarterly Journal of Economics, 109(2), 465-490. doi.org/10.2307/2118470

Romer, P. M. (1986). Increasing returns and long-run growth. Journal of political economy, 94(5), 1002-1037. doi/abs/10.1086/261420

Slack, E., \& Bird, R. (2014). The political economy of property tax reform. OECD Working Papers on Fiscal Federalism. doi.org/10.1787/22265848
Stockman, A. C. (1981). Anticipated inflation and the capital stock in a cash in-advance economy. Journal of monetary economics, 8(3), 387-393. doi.org/10.1016/0304-3932(81)90018-0

Stoilova, D. (2017). Tax structure and economic growth: Evidence from the European Union. Contaduría y Administración, 62(3), 1041-1057. doi.org/10.1016/j. cya.2017.04.006

Solow, R. M. (1957). Technical change and the aggregate production function. Review of Economics and Statistics, 39(3), 312-320. doi.org/10.2307/1926047

Tosun, M. S. \& Abizadeh, S. (2005). Economic growth and tax components: An analysis of tax change in OECD. Applied Economics, 37(19), 2251-2263. doi/abs/10.1080/00036840500293813

Vasiliauskaitè, A., \& Stankevičius, E. (2009). Tax burden management and GD growth: Case of EU countries. Economics \& Management, 14, 202-209. doi:10.5755/j01. em.0.14.9301P

Wang, D. H.-M. (2007). Convergence tests on tax burden and economic growth among China, Taiwan and the OECD countries. Physica A: Statistical Mechanics and its Applications, 380, 278-286. doi.org/10.1016/j.physa.2007.02.046

Widmalm, F. (2001). Tax structure and growth: Are some taxes better than others? Public Choice, 107(3-4), 199-219. doi.org/10.1023/A:1010340017288

Xing, J. (2012). Tax structure and growth: How robust is the empirical evidence? Economics Letters, 117(1), 379-382. doi.org/10.1016/j.econlet.2012.05.054

Zagler, M., \& Dürnecker, G. (2003). Fiscal policy and economic growth. Journal of economic surveys, 17(3), 397-418. doi.org/10.1111/1467-6419.00199

Zaharia, M., Pătrașcu, A., Gogonea, M., Tănăsescu, A., \& Popescu, C. (2017). A cluster design on the influence of energy taxation in shaping the new EU-28 economic paradigm. Energies, 10(2), 1-21. doi.org/10.3390/en10020257 


\section{Received on $3^{\text {rd }}$ May 2021, after revision, accepted for publication on $25^{\text {th }}$ November 2021 \\ Published online on $6^{\text {th }}$ December 2021}

Lich Khac Hoang received his $\mathrm{PhD}$ degree from the University of the Thai Chamber of Commerce. He is currently a lecturer at the Faculty of Development Economics, VNU University of Economics and Business. His research interests include Economic Growth, Sustainable Development and Poverty Reduction.

Cao Tan Binh is Vice Director of Center of Economics and Accounting, Quy Nhon University, Vietnam; and a lecturer at the Department of Economics and Accounting, Quy Nhon University, Vietnam. He is currently a PhD Student in Probability theory and mathematical statistics, at the VNU University of Science, Vietnam. His research interests are Statistics, Financial mathematics, Econometrics, Stochastic Process.

Kim My Le is currently a lecturer at Quy Nhon University, majoring in Development Economics. She is interested in research topics such as household welfare, supply chain management, risk management, economic growth and sustainable economic development.

Dung Thi Thuy Nguyen is a lecturer who works for Quy Nhon University majoring Development Economics. Her research interest include economic growth, income inequality, women's empowerment and sustainable livelihood development. 


\section{APPENDIX}

Table 1 The descriptive statistics

\begin{tabular}{|c|c|c|c|c|c|c|}
\hline Variable & Classified Group & Obs & Mean & Std. Dev & Min & Max \\
\hline \multirow[t]{3}{*}{ GDP per capita growth rate } & Group 1 & 420 & 3.58 & 3.89 & $-14 \cdot 38$ & 17.03 \\
\hline & Group 2 & 285 & 0.79 & 2.98 & -8.51 & 23.98 \\
\hline & Group 3 & 240 & 1.53 & 3.66 & -14.277 & 10.8 \\
\hline \multirow[t]{3}{*}{ Personal income tax } & Group 1 & 420 & 2.2 & 2.1 & 0 & 9.9 \\
\hline & Group 2 & 285 & 4.2 & 1.7 & 0.9 & 8.3 \\
\hline & Group 3 & 240 & 10.4 & 4.2 & 4.3 & 26.2 \\
\hline \multirow{3}{*}{ Corporate income tax } & Group 1 & 420 & 2.7 & 1.5 & 0 & 8.1 \\
\hline & Group 2 & 285 & 2.6 & 1 & 0.8 & 6.5 \\
\hline & Group 3 & 240 & 3 & 1 & 1.2 & 7.2 \\
\hline \multirow[t]{3}{*}{ Property tax } & Group 1 & 420 & 0.2 & 0.3 & 0 & 1.6 \\
\hline & Group 2 & 285 & 0.6 & 0.6 & 0 & 2.9 \\
\hline & Group 3 & 240 & 1.8 & 1 & 0.2 & 4.2 \\
\hline \multirow[t]{3}{*}{ Trade tax } & Group 1 & 420 & 2.3 & 4.3 & -1.6 & 0 \\
\hline & Group 2 & 285 & 0.3 & 0.5 & -0.01 & 3.9 \\
\hline & Group 3 & 240 & 0.08 & 0.15 & -0.007 & 0.86 \\
\hline \multirow[t]{3}{*}{ Good and Service tax } & Group 1 & 420 & 8.8 & 3.5 & 2.4 & 22.1 \\
\hline & Group 2 & 285 & 11.9 & 2.7 & 4.1 & $17 \cdot 3$ \\
\hline & Group 3 & 240 & 10.2 & 3 & 4 & 16.7 \\
\hline \multirow[t]{3}{*}{ Other tax } & Group 1 & 420 & 0.37 & 0.6 & -0.000512 & 4.8 \\
\hline & Group 2 & 285 & 0.17 & 0.39 & -0.39 & 3.38 \\
\hline & Group 3 & 240 & 0.12 & 0.3 & 0 & 1.5 \\
\hline \multirow[t]{3}{*}{ Social Security Contribution } & Group 1 & 420 & 2.04 & 3.7 & -0.05 & 15.5 \\
\hline & Group 2 & 285 & 8.4 & 4.4 & 0 & 15 \\
\hline & Group 3 & 240 & 8.99 & 4.96 & 0 & 16.92 \\
\hline \multirow[t]{3}{*}{ Inflation } & Group 1 & 420 & 6.14 & 5.94 & -18.11 & 51.46 \\
\hline & Group 2 & 285 & 3.29 & 3.09 & -1.54 & 21.6 \\
\hline & Group 3 & 240 & 1.54 & 1.22 & -4.48 & 4.9 \\
\hline \multirow[t]{3}{*}{ Investment rate } & Group 1 & 420 & 5.59 & 14.97 & -57.4 & 53.98 \\
\hline & Group 2 & 285 & 1.91 & 9.74 & -23.85 & 52.08 \\
\hline & Group 3 & 240 & 1.29 & 13.44 & -42.33 & 72.17 \\
\hline \multirow[t]{3}{*}{ Export to GDP } & Group 1 & 420 & 36.54 & 12.25 & 11.15 & 71.42 \\
\hline & Group 2 & 285 & 55.32 & 27.94 & 20.45 & 165.21 \\
\hline & Group 3 & 240 & 53.73 & 41.83 & 9.04 & 224.84 \\
\hline \multirow[t]{3}{*}{ Population growth } & Group 1 & 420 & 1.14 & 1.04 & -1.75 & 5.43 \\
\hline & Group 2 & 285 & 0.19 & 0.91 & -2.26 & 2.74 \\
\hline & Group 3 & 240 & 0.75 & 0.6 & -1.85 & 2.89 \\
\hline \multirow[t]{3}{*}{ Gross saving } & Group 1 & 420 & 22.78 & 10.23 & 3.84 & 53.05 \\
\hline & Group 2 & 285 & 21.85 & 41.87 & 9.73 & 36.12 \\
\hline & Group 3 & 240 & 24.61 & 5.6 & 11.05 & 39.66 \\
\hline \multirow{3}{*}{ Human development index } & Group 1 & 420 & 0.69 & 0.07 & 0.5 & 0.81 \\
\hline & Group 2 & 285 & 0.9 & 0.02 & 0.85 & 0.94 \\
\hline & Group 3 & 240 & 0.87 & 0.03 & 0.8 & 0.92 \\
\hline
\end{tabular}

Source: Authors 
Table 2 The countries classification

\begin{tabular}{|c|c|c|}
\hline Group 1 & Group 2 & Group 3 \\
\hline Armenia & Bulgaria & Australia \\
\hline Bangladesh & Chile & Austria \\
\hline Bosnia and Herzegovina & Czechia & Belgium \\
\hline Bhutan & Estonia & Canada \\
\hline China & Croatia & Switzerland \\
\hline Cabo Verde & Hungary & Germany \\
\hline Costa Rica & Israel & Denmark \\
\hline Dominican Republic & Korea, Rep. & Finland \\
\hline Ghana & Lithuania & France \\
\hline Guatemala & Latvia & United Kingdom \\
\hline Honduras & Mexico & Ireland \\
\hline Jamaica & Malta & Japan \\
\hline Jordan & Mauritius & Luxembourg \\
\hline Cambodia & Poland & Netherlands \\
\hline Sri Lanka & Portugal & Sweden \\
\hline Lesotho & Romania & United States \\
\hline Morocco & Slovakia & \\
\hline Moldova & Slovenia & \\
\hline Nicaragua & Turkey & \\
\hline \multicolumn{3}{|l|}{ Peru } \\
\hline \multicolumn{3}{|l|}{ Philippines } \\
\hline \multicolumn{3}{|l|}{ Paraguay } \\
\hline \multicolumn{3}{|l|}{ El Salvador } \\
\hline \multicolumn{3}{|l|}{ Togo } \\
\hline \multicolumn{3}{|l|}{ Thailand } \\
\hline \multicolumn{3}{|l|}{ Tunisia } \\
\hline \multicolumn{3}{|l|}{ Ukraine } \\
\hline South Africa & & \\
\hline
\end{tabular}

Source: Authors 


\title{
OPOREZIVANJE I EKONOMSKI RAST: REGRESIONA ANALIZA ZASNOVANA NA NOVOJ KLASIFIKACIJI
}

\author{
Lich Khac Hoang', Binh Tan Cao², Kim My Le² i Dung Thi Thuy Nguyen² \\ ${ }^{1}$ Vietnam National University, University of Economics and Business, Hanoi, Vietnam \\ ${ }^{2}$ Quy Nhon University, Quy Nhon, Vietnam
}

U radu se ispituje uticaj poreza na ekonomski rast, zasnovan na analizi indikatora BDP-a per capita i poreskih obavezah, za zemlje koje su razvrstane u tri grupe, prema nivou razvijenosti. Koristi se tehnika particionisanja oko medoida (PAM tehnika), zato što ista nije preosetljiva na izuzetke. Ova višekriterijumska tehnika podrazumeva korišćenje metoda uopštenih momenata (GMM) za analizu podataka, za tri grupe koje čine 63 zemlje, u periodu 2003-2017. Rezultati istraživanja pokazuju da većina poreza ostvaruje pozitivan uticaj na ekonomski rast u siromašnim zemljama (Grupa 1). Ukazuje se da porezi na robu i usluge promovišu ekonomski rast u bogatim zemljama (Grupa 3), umesto da imaju negativan učinak, kao što se zaključuje u nekim prethodnim studijama. To se posebno odnosi na porez na imovinu koji, dok ostvaruje negativan učinak na ekonomski rast u bogatim zemljama, ima značajno pozitivan učinak u siromašnim zemljama.

Ključne reči: poreska struktura, ekonomski rast, tehnika formiranja klastera, GMM procena

JEL Classification: E62, Ho, $\mathrm{O} 47$ 